\title{
STRATEGI PEMASARAN PRODUK PEMBIAYAAN WARUNG MIKRO \\ PADA BANK SYARIAH MANDIRI KANTOR CABANG PROBOLINGGO
}

\author{
Maula Nasrifah \\ Email: maula403@gmail.com \\ Universitas Zainul Hasan Genggong Probolinggo
}

Aimatus Sholehah

Universitas Zainul Hasan Genggong Probolinggo

\begin{abstract}
The purpose of this study to determine marketing strategy of Warung Micro finance products at Probolinggo Branch Office of Bank Syariah Mandiri as well as to determine the supporting and inhibiting factors for marketing the product.

This study using a descriptive qualitative approach to the type of field research (flied research) through observations about a phenomenon. Data collection techniques are done by observation, interview, and documentation.

The results of this study explain that the marketing strategy used by the Bank Syariah Mandiri Proboliggo Branch Office in an effort to achieve the target marketing of Warung Micro Fianance Products use a marketing mix strategy consist of Product, Price, Place and Promotion. While the promotion strategy used is a door to door strategy, advertising promotion strategy, pricing strategy, top-up strategy and product strategy. Supporting factors in the marketing of microfinance products are competitive product, low price and strategic location. While the inhibiting factors are the lack of public knowledge about the operational system of Islamic banks, competition between banks and the lack of human resources, especially human resources, microfinance sales so that marketing the product to the wider community takes a long time.
\end{abstract}

Keyword: Strategy, Product, Finance 


\section{PENDAHULUAN}

Perkembangan ekonomi dunia terus meningkat seiring dengan berjalannya waktu.Persaingan bisnis semakin nampak dan menuntut para pelaku bisnis untuk dapat terus bertahan dalam kondisi perekonomian yang kompetitif.Persaingan antara produsen untuk dapat memahami kebutuhan konsumen serta kepuasan kepada para pelanggan secara maksimal sangatlah dibutuhkan, karena kepuasanterhadap para pelanggan merupakan tujuan utama dalam sebuah bisnis. Oleh karena itu, setiap perusahaan dituntut untuk memiliki strategi dalam menghadapi persaingan usaha. Begitu juga dengan dunia usaha pada bidang perbankan.

Bank merupakan lembaga keuangan yang usahanya adalah menerima simpanan dari masyarakat dan menyalurkan dana kepada masyarkat dengan skema kredit atau bentuk yang lain. Dalam menghadapi persaingan yang ketat, bank harus melakukanupaya-upaya dengan maksimal dalam rangka pembaharuan dengan usaha yang maksimal untuk menjadi pemain utama dalam segmen usahanya. Sehingga, dapat menjadi preferensi utama pelanggan yang berujung kepada kepuasan dan loyalitas pelanggan dalam hal ini nasabah. Persaingan bisnis saat ini sangatlah ketat. Perusahaan bersaing dalam memberikan fasilitas dansarana prasarana dalam memenuhi kebutuhan dan keinginan nasabah. Hal ini juga terjadi pada industri perbankan syariah.

Perbankan syariah merupakan bank yang mengacu kepadahukum syariah islam yang artinya sistem yang dijalankan pada bank syariah ini berdasarkan kepada larangan bunga dalam transaksi pinjaman/simpanan yang disebut dengan riba.Dalam menghindari riba tersebut, bank syariah menggunakan prinsip bagi hasilbaik terhadap produk simpanan (pada tabungan maupun deposito) maupun produk pembiayaan terhadap modal kerja dan investasi. ${ }^{1}$

Dengan banyaknya lembaga keuangan yang bermunculan di tengah masyarakat, maka perbankan syariah dituntut untuk terus meningkatkan kinerjaagar tetap unggul dan dapat bersaing. Dalam usaha memperkenalkan produk kepada para konsumen, bank syariah membutuhkan sebuah kegiatan pemasaran yakni memasarkan atau mempromosikan produk kepada calon nasabah baru dengan menggunakan strategi-strategi jitu agar dapat mempromosikan dengan baik. $^{2}$

Strategi didefinisikan sebagai cara yang digunakan untuk menentukan tujuan pencapaian sebuah organisasi yang harapannya dapat mengimplementasikan misi sebuah usaha. Makna yang terkandung dari strategi ini adalah bahwa manajer memiliki peran aktif, sadar dan rasional dalam merumuskan strategi organisasi yang dipimpinnya. ${ }^{3}$

Dalam menjalankan strategi pemasaran, seorang pimpinandituntut untuk dapat memberi gambaran yang jelas pasti dan terarah tentang kegiatan yang akan dilakukan oleh perusahaan dalam memaksimalkan kesempatan yang ada ataupun memaksimalkan peluang terhadap beberapa pasar yang menjadi target sasaran. Semua perusahaan melakukan strategi pemasaran untuk dapat menarik pelanggan serta usaha untuk menguasai pasar. Pemasaran mempunyai peran untuk menjalankan fungsi organisasi dalam rangka menciptakan dan mengkomunikasikan produk kepada para pelanggan, dan memberikan nilai kepada para pelanggan untuk dapat mengelola hubungan dengan menggunakan cara yang dapat memberi keuntungan bagi

${ }^{1}$ Saefuddin, A. M, Membumikan Ekonomi Islam (Jakarta: PT. PPA Consultants, 2011), hlm.

${ }^{2}$ Sofjan Assauri, Manajemen Pemasaran (Jakarta: PT. Raja Grafindo Persada, 2011), hlm. 167. ${ }^{3}$ Fandy Tjiptono, Strategi Pemasaran (Yogyakarta: Andi Offset, 1997), hlm. 3 
organisasi dan bagipara pemangku kepentingan, oleh karena itu pemasaran memiliki peran yang sangat penting dalam mengembangkan strategi perusahaan.

Dalam kehidupan masyarakat saat inidituntut untuk memenuhi kebutuhan sehari-hari, mulai dari kebutuhan primer, skunder maupun tersier. Untuk itu, perbankan syariah mempunyaiproduk yang dapat membantu masyarakatdalam memenuhi kebutuhan dimaksud.Produk pembiayan dimaksud adalah produk pembiayaan warung mikropada Bank Syariah Mandiri.

Pembiayaan warung Mikro merupakan pembiayaan khusus usaha kecil atau perorangan dalammemenuhi kebutuhan modal kerja maupun investasi dengan modelpembiayaan dengan skema angsuran. Pembiayaan warung mikro ditujukan kepada calon nasabah yang tidak memiliki jaminandan tidak dapat memiliki fasilitas pembiayaan yang lain.

Strategi pemasaranyang dibutuhkan oleh produk warung mikro haruslah strategi yang baik dan jitu, karena strategi pemasaran mempunyai kekuatan besar bagi konsumen.Dengan ketatnya persaingan pada dunia perbankan syariah, maka bank syariah dituntut untuk lebih inovatif dan lebih jeli didalam menggunakan strategi pemasaran yang baik agar dapatmencapai tujuan yang sesuai dengan yang diharapkan oleh perusahaan.

Pada produk Warung Mikro ini, Bank Syariah Mandiri Kantor Cabang Probolinggo harus senantiasaterus melakukan upaya untuk memberikan kepuasan nasabah dengan berbagai cara yang harus dilakukan agar dapat menghadapi persaingan yang semakin ketat sehingga nasabah tidak berpindah kepadabank lainyang lebih menguntungkan dengan pelayanan yang lebih maksimal. Untuk itu, Bank Syariah Mandiri menggunakan strategi pemasaran khusus dalam menawarkan produk pembiayaan warung mikro dengan memperhatikan Faktor pendukung dan penghambatnya.

\section{METODE PENELITIAN}

Penelitian ini bersifat deskriptif dengan tujuan untuk menggambarkan fakta saat ini dari suatu kelompok yang berkaitan dengan pendapat kejadian/prosedur secara sistematik dan akurat. Pendekatan yang diguankan adalah pendekatan kualitatif dengan jenis penelitian lapangan (field study).Sumber data berasal dari data primer melalui wawancara langsung dengan petugas terkait tentang strategi pemasaran pada Produk Pembiayaan Warung Mikropada Bank Syariah Mandiri Kantor Cabang Probolinggo yang terletak di komplek Ruko Manunggal Jl.Soekarno-Hatta No. 2 Kav.7 probolinggo.

Tekhnik pengumpulan data dilakukan melalui proses pengamatan (observasi) dengan mengamati langsung praktik yang terjadi dengan mencari kesesuaian antara keterangan yang didapat dengan praktik yang dilakukan oleh tim marketing sehingga data yang diperoleh memiliki keandalan yang tinggi karena dapat dipantau dengan seksama oleh peneliti. Tekhnik pengumpulan data juga dilakukan dengan melalui wawancara kepada Bapak Abdullah Najib selaku kepala cabang, Ibu Noor Fajriana selaku manajer bank mini, bapak Ahmad Ghufron Wahid dan Nasrullah Efendiselaku Marketing produk pembiyaan warung mikro. Selanjutnya, Teknik dokumentasi dilakukan untuk melengkapi data yang diperoleh.Metode ini digunakan untuk memperoleh data dan dokumen pendukung yang berkaitan dengan penelitian. 


\section{LANDASAN TEORITIK}

\section{A. Strategi Pemasaran}

Strategi didefinisikan sebagai program untuk menentukan dan mencapaitujuan organisasi dalam mengimplementasikan misi yang diembannya. Makna yang terkandung dari strategi ini adalah peran para manajer yang dituntu aktif, sadar dan rasional dalam merumuskan strategi sebuah organisasi. Dalam Kamus Umum Bahasa Indonesiadisebutkan bahwa strategi merupakan ilmu siasat perang atau akal (tipu muslihat) untuk mencapai sesuatu suatu yang dimaksud. ${ }^{4}$ Artinyasemua perusahaan memiliki strategi, namun tidak semua dirumuskan secara eksplisit. Terutama bagi manajer yang memiliki sifat reaktif yang pasif dan sulit menyesuaiakn diri dengan lingkungan.

Pemasaran merupakan sebuah sistem kegiatan saling berhubunganmulai dari perencanaan, penentuan harga, mempromosikan dan mendistribusikan barang dan jasa terhadappara pelanggan. ${ }^{5}$ Secara umum pemasaran bank dapat diartikan sebagai suatu proses yang dilakukan untuk menciptakan dan menukarkan produk atau jasa perbankandengan tujuan untuk memenuhi kebutuhan para nasabah dengan memberikan kepuasan kepada nasabah. ${ }^{6}$

Pemasaran menjawab kenyataan bahwa manusia memiliki kebutuhan dan keinginan dengan memilih produk yang ditentukan oleh konsep nilai, biaya, kepuasan dengan memilihproduk yang tepat didalammemenuhi kebutuhan pribadinya. Pemasaran disebut pula sebagaiserangkaianprinsip yang digunakan untuk memilih pasar agar sasaran, kemudian mengevaluasi kebutuhan konsumen, mengembangkan barang dan jasa, sebagai alat yang dapat memberikan kepuasan atas keinginan dan memberikan nilai kepada konsumen dan perusahaan. Dalam falsafah bisnis, Konsep pemasaran dikatakan sebagai pemuasan kebutuhan konsumen yang dapat menyebabkan kelangsungan hidup bagi perusahaan.?

Konsep pemasaran berdiri pada empat tiang utama, yakni Pertama, fokus pasar artinya perusahaan akan berhasil baik apabila mereka mempersiapkan program pemasaran yang sesuai dengan kebutuhan pasar yang menjadi target sasaran. Kedua, orientasi kepada pelanggan artinya mengharuskan perusahaan secara cermat untuk dapatmenentukan kebutuhan pelanggan dengan menggunakan sudut pandang pelanggan bukan dengan sudut pandang sendiri. Ketiga, pemasaran yang terkoordinasi artinya seluruh karyawan menyadari bagaimana dampak usaha yang akan dilakukan terhadap kepuasan para pelanggan. Keempat, kemampuan labaartinya perusahaan dapat menghasilkan keuntungan dengan memuaskan kebutuhan pelanggan lebih baik dari pada yang dapat dilakukan pesaing. Dimana hal ini disebabkan karena banyak produk yang tepat memenuhi suatu kebutuhan. Dapat dikatakan pula bahwa pemasaran terdiri dari serangkaian caradidalam memilih pasar yang menjadi target sasaran, mengevaluasi kebutuhan konsumen, mengembangkan barang dan jasa, memberikan kepuasan bagi keinginan konsumen dan dapat memberikan nilai kepada konsumen dan bagi perusahaan.

Konsep pemasaran merupakan sebuah falsafah bisnis yang menyatakan bahwa pemuasan kebutuhan konsumen menyebabkan kelangsungan hidup perusahaan. Dalam perkembangannya strategi pemasaran modern dapat dideskripsikan melalui 3 kunci yaitu:

\footnotetext{
${ }^{4}$ W.J.S Poerwadarminta, Kamus Umum Bahasa Indonesia, Cet. 6 (Jakarta: Balai Pustaka, 1983), hlm. 956.

${ }_{5}^{5}$ Basu Swastha dan Irawan, Manajemen Pemasaran Modern (Yogyakarta: Penerbit Leberty, 1997), hlm. 5.

${ }^{6}$ Crown Dirgantoro, Manajemen Stratejik (Jakarta: PT Grasindo, 2001), hlm. 5.

${ }^{7}$ Mudrajat Kuncoro, Manajemen Perbankan, Teori dan Aplikasi, (Yogyakarta: BPFE, 2001), hlm. 66.
} 
1. Marketing Mix, Marketing mixmerupakan sebuah strategi yang menekankan penjualan produk secara efektif dengan mengacu kepada data-data yang diperoleh dan dikumpulkan dari pelanggan, agar proses penjualan berjalan dengan lancar sesuai dengan yang daharapkan. Dengan kata lain marketing mix merupakan variabel-variabel yang digunakan di setiap perusahaan sebagai sarana untuk memenuhi kebutuhan dan keinginan konsumen. ${ }^{8}$ Variabel - variabel tersebut sering di sebut dengan $4 \mathrm{P}$, Elemen yang ada dalam marketing mix yaitu ${ }^{9}:$ 1) Product, Produk yang secara umum diartikan sebagai sesuatu yang dapat memenuhi kebutuhan dan keinginan para pelanggan. Artinya apapun wujud produk tersebut dapat memenuhi keinginan dan kebutuhan pelanggan. 2) Price,Penentuan harga menjadi sangat penting untuk diperhatikan, mengingat harga sangat menentukan laku tidaknya sebuah produk dan jasa. 3) Placeyakni Penentuan lokasi kantor serta sarana dan prasarana juga agar nasabah mudah menjangkau setiap lokasi yang ada tentu dengan difasilitasi sarana dan prasarana harus memberikan rasa yang nyaman dan aman kepada seluruh nasabah yang berhubungan dengan bank.4) Promotionyaknimempromosikan seluruh produk dan jasa yang dimiliki oleh perusahaan baik langsung maupun tidak langsung. Promosi merupakan sarana yang sangat ampuh untuk menarik dan mempertahankan nasabah.Secara garis besar kelompok promosi, yaitu: Periklanan (Advertasing),personal selling dan publisitas.

2. Market Share(pangsa pasar) adalah sebuah indikator tentang apa yang dilakukan oleh sebuah perusahaan terhadap kompetitornya dengan dukungan perusahaan-perusahaan terhadap sales. Pemahaman mengenai pangsa pasar akan membantu manajemen perusahaan untuk mengevaluasi keberhasilan upaya didalam menembus pasar terhadap kompetitornya. Pangsa pasar akan naik jika perusahaan menurunkan harga jual produknya secara signifikan akan tetapi itu pula bisa membuat revenue perusahaan turun. Oleh karena itu, perusahaan harus membuat kebijakan yang mampu meningkatkan pangsa pasar. Market Share adalah memecah-mecah suatu keseluruhan yang homogen menjadi bagian yang mencangkup para pelanggan yang mempunyai kepentingan sama untuk tujuan yang berbeda-beda. ${ }^{10}$

3. Positioning(Posisi pasar) adalah segala upaya untuk mendesain produk atau merk agar dapat menempati sebuah posisi yang unik dimata pelanggan. Hasil akhir dari positioning adalah terciptanya proporsi nilai yang pas yang menjadi alasan bagi pelanggan untuk membeli. Dengan kata lain positioning adalah tindakan merancang sebuah produk dan bauran pemasaran agar dapat memberikan kesan baikser dimata masyarakat. ${ }^{11}$

4. Segmentasi, merupakan kegiatan membagi suatu pasar menjadi kelompok-kelompok pembeli yang berbeda yang memiliki kebutuhan, karakteristik, atau perilaku yang berbeda yang mungkin membutuhkan produk dengan pemasaran yang berbeda. Atau segmentasi pasar bisa diartikan sebagai proses pengidentifikasian dan menganalisis para konsumen di pasar, menganalisa perbedaan para konsumen di pasar.

\footnotetext{
${ }^{8}$ Basu Swasta, et al, Manajemen Pemasaran Modern (Yogyakarta: Liberty Yogyakarta, 1997), hlm. 5.

${ }^{9}$ Kasmir, Pemasaran Bank (Jakarta: Kencana Prenada Media Group, 2010), hlm. 119

${ }^{10}$ David Hunger dan Thomas Wheelen, Manajemen Strategis (Yogyakarta: Penerbit Andi, 2003), hlm. 16.

${ }^{11}$ M. Murid, Manajemen Pemasaran (Jakarta: PT. Bumi Aksara, 2008), hlm. 69.
} 
Dalam dunia usaha strategi atau taktik sangat mutlak diperlukan untuk menunjang kemajuan perusahaan. Selalu akan ada kebutuhanpenjualan dan membuat penjualan berlimpah. Tujuan pemasaran adalah mengetahui dan memahami pelanggan dengan baik sehingga produk atau jasa bisa sesuai dengan kebutuhanpelanggan. Dalam praktiknya tujuan suatu perusahaan dapat bersifat jangka pendek maupun jangka panjang. Dalam jangka pendek biasanya hanya besifat sementara dan juga dilakukan sebagai langkah untuk mencapai tujuan jangka panjang. Hal ini berlaku juga pada perusahaan bidang perbankan.

Secara umum tujuan pemasaran bank adalah untuk: (1) Memaksimalkan konsumendengan cara memeberikn kemudahan dengan cara yang baik,sehingga dapat menarik nasabah untuk membeli produk yang ditawarkan dengan cara berulang-ulang. (2) Memaksimumkan pilihan dalam arti bank menyediakan produk sehingga nasabah memiliki beragam pilihan. (3) Memaksimumkan kepuasan pelangan melalui berbagai pelayanan yang diinginkan nasabah. Nasabah yang puas akan menjadi ujung tombak pemasaran selanjutnya, karena kepuasan ini akan ditularkan kepada nasabah yang lain.

Ada beberapa jenis strategi pemasaran yang dapat ditempuh perusahaan dalam melakukan strategi pemasaran sebuah produk, yaitu ${ }^{12}$ : (1) Strategi yang tidak membeda-bedakan pasar. Maksudnya, menganggap pasar sebagai suatu keseluruhan, sehingga perusahaan hanya memperhatikan kebutuhan konsumen secara umum, sehingga hanya menghasilkan dan mempromosikan satu macam produk saja dan berusaha menarik semua pembeli dan calon pembeli dengan suatu rencana pemasaran saja.(2) Strategi pemasaran dengan membedakan pasar (Differentiated Marketing). Artinya, perusahaan hanya melayani kebutuhan beberapa kelompok konsumen tertentu dengan jenis produk tertentu pula. Jadi, perusahaan atau produsen menawarkan berbagai variasi produk dan product mix yang disesuaikan dengan kebutuhan dan keinginan kelompok konsumen atau pembeli yang berbeda-beda, dengan program pemasaran ini diharapkan dapat mencapai tingkat penjualan yang tinggi dalam masing-masing segmen pasar tersebut. (3) Strategi pemasaran yang terkonsentrasi (Concentrated Marketing). Pada strategi ini perusahaan mengkhususkan pemasaran produk dengan menggunakan beberapa segmen pasar, yakni dengan mempertimbangkan keterbatasan sumber daya perusahaan, produsen memilih segmen pasar tertentu dan menawarkan produk yang sesuai dengan kebutuhan dan keinginan kelompok konsumen yang ada pada segmen pasar tersebut dengan lebih spesifik. ${ }^{13}$

${ }^{12}$ Ismail Nawawi Uha, Isu-Isu Ekonomi Islam 4 Nalar Bisnis (Jakarta: VIV Press Jakarta, 2013), hlm. 681.

${ }^{13}$ Ibid, h.179-181 
Didalam melakukan aktifitas pemasaran produk yang bertujuan agar dikenal oleh masyarakat dan dapat meningkatkan volume penjualan,tentu menghadapi hambatan, namun hambatan dalam pemasaran juga sering terjadi yang akibat ketidaktahuan pelaku pemasaran dalam hal ini tim marketing.Adapun hambatan yang sering terjadi sebagai betikut: (1) Melakukan Promosi dengan kurang tepat. Kegiatan promosi merupakan sebuah trik jitu dalam memasarkan produk, karena kita akan mengetahui respon konsumen atas produk yang ditawarkan. Contoh, dengan menawarkan diskon disetiap periode tertentu dapat menggugah minat konsumen untuk membelinya. (2) Banyaknya Persaingan antar perusahaan dimana para pesaing adalah perusahaan yang menjual barang dan jasa yang sama dengan produk yang ditawarkan.

\section{B. Produk Pembiayaan}

Produk Pembiayaan atau financing adalah salah satu produk pembiayaanpada Bank Syariah untuk mendukung investasi yang telah direncanakan oleh nasabah. Pembiayaan berdasarkan UU No. 21 tahun 2008 adalah penyediaan dana atau tagihan yang dipersamakan dengan itu berupa:

1. Transaksi bagi hasil dalam bentuk Mudharabah dan Musyarakah.

2. Transaksi sewa menyewa dalam bentuk ijarah atau sewa beli dalam bentuk Ijarah AlMuntahiya Bit Tamlik.

3. Transaksi jual beli dalam bentuk piutang Murabahah, Salam, dan Istisnha'

4. Transaksi pinjam meminjam dalam bentuk piutang qardh.

5. Transaksi sewa menyewa jasa dalam bentuk ijarah untuk transaksi multijasa berdasarkan persetujuan atau kesepakatan antara bank syariah dan/atau UUS dan pihak lain yang mewajibkan pihak yang dibiayai dan/atau diberi fasilitas dana untuk mengembalikan dana tersebut setelah jangka waktu tertentu dengan imbalan ujrah, tanpa imbalan, atau bagi hasil.

Menurut Kasmir unsur yang terkandung dalam pembiayaan syariah ada 4 yaitu $^{14}$ : (1) Kepercayaan, yaknikeyakinan pihak pemberi dana bahwa dana yang dipinjamkan akan dikembalikan dimasa yang akan datang. (2) Kesepakatan, Kesepakatan diwujudkan dalam bentuk perjanjian yang masing-masing pihak menandatangani hak dan kewajibannya.(3) Jangka waktu, yakni mencakup masa atau waktu pengembalian/pembayaran pembiayaan. (4) Resikokerugian,maksudnya adalah resiko tidak terbayaranya pembiayaan oleh nasabah. Dalam hal ini dapat diakibatkan dua yaitu kesengajaan nasabah yang tidak mau mengembalikan dana, padahal nasabah mampu untuk mengembalikan, dan karena terjadinya sebuah bencana.

Konsep pembiayaan murabahah pada perbankan syari'ah pada dasarnya bank tidak memiliki barang yang diinginkan oleh nasabah, sehingga bank harus melakukan transaksi pembelian atas barang yang diinginkan oleh nasabah kepada pihak lain yang disebut sebagai supplier. Dengan demikian, bank bertindak sebagai pembeli. Kemudian, bank akan menjualnya kembali kepada nasabah dan bank tersebut bertindak sebagai penjual dengan harga yang disesuaikan yakni harga beli ditambah margin yang disepakati. ${ }^{15}$

Adapun karakteristik pembiayaan yang dipraktekkan oleh perbankan syariah syari'ah adalah sebagai berikut: (1) Akad yang digunakan adalah akad jual beli(murabahah). Implikasi

${ }^{14}$ Kasmir, Manajemen Perbankan (Jakarta: PT Raja Grafindo Persada, 2004), hlm. 75-76.

\footnotetext{
${ }^{15}$ Muhamad Syafiee i Antonio, Bank Syariah dari Teori ke Praktek (Jakarta: Gema Insani, 2001), hlm.101.
} 
dari adanya transaksi jual beli mengharuskan adanya pembeli, penjual dan barang yang dijual. Bank syari'ah sebagai penjual harus menyediakan barang untuk nasabah yang dalam hal ini adalah sebagai pembeli. Sehingga nasabah berkewajiban untuk membayar barang yang telah diserahkan oleh bank syari'ah. (2) Harga yang ditetapkan oleh pihak penjual (bank syari'ah) tidak dipengaruhi oleh frekuensi waktu pembayaran. Jadi, harga yang sudah sesuai dengan isi perjanjian dan telah ditetapkan di dalam kontrak.(3) Keuntungan dalam pembiayaan berbentuk margin penjualan yang sudah termasuk harga penjualan. Keuntungan tersebut sewajarnya dapat dinegosiasikan antara pihak bank dan nasabah. (4) Pembayaran harga barang dapat dilakukan secara angsuran. (5) Dalam pembayaran pembiayaan memungkinkan adanya jaminan, karena sifat dari pembiayaan ini merupakan jual beli yang pembayarannya tidak dilakukan secara tunai.

Pengelompokan pembiayaan berdasarkan tujuan pembiayaan ada 2 (dua) kelompok yaitu ${ }^{16}$ : (1) Pembiayaan Konsumtif yangbertujuan untuk memperoleh barang-barang atau kebutuhan-kebutuhan yang lainuntuk memenuhi keputusan dalam konsumsi. Pembiayaan konsumsi dibagi menjadi dua bagian yaitu pembiayaan konsumtif untuk umum dan pembiayaan konsumtif untuk pemerintah. (2) Pembiayaan Produktif yang bertujuan untuk memungkinkan penerima pembiayaan dapat mencapai tujuannya yang apabila tanpa pembiayaan tersebut tidak mungkin dapat diwujudkan. Pembiayan produktif adalah bentuk pembiayaan yang bertujuan untuk memperlancar jalannya proses produksi, mulai dari saat pengumpulan bahan mentah, pengolahan dan sampai kepada proses penjualan barang-barang yang sudah jadi.

\section{Prinsip Pemberian Pembiayaan}

Tujuan pembiayaan adalah untukmengoptimalkan laba, meminimkan resiko, mendayagunakan sumberdaya ekonomi yang ada dan menyalurkan kelebihan dana. Dalam pemberian pembiayaan terdapat beberapa analisa yang harus dilakukan untuk mengetahui kelayakan calon penerima pembiayaan. Analisa tersebut melalui analisa 5C . Pengertian analisa 5C yaitu: ${ }^{17}$

a. Character; Untuk memberikan keyakinan kepada bank bahwa, sifat atau watak calon nasabah benar-benar dapat dipercaya. Hal ini dapat diihat dari latar belakang calon nasabah baik dari pekerjaan ataupun sosial masyarakat.

b. Capacity; Untuk melihat kemampuan nasabah dalam membayar pembiayaan yang dihubungkan dengan kemampuan nasabah didalam mengelola bisnis dan mencari keuntungan.

c. Capital; Untuk mengetahui sumber pembiayaan yang dimiliki nasabah terhadap usaha yang akan dibiayai oleh Bank nantinya.

d. Collateral; Merupakan jaminan yang diberikan calon nasabah kepada bank. Nilai jaminan hendaknya melebihi jumlah pembiayaan yang akan diberikan. Seningga jika terjadi suatu masalah jaminan yang diberikan dapat digunakan untuk memenuhi kewajiban nasabah yang bermasalah.

e. Condition; Dalam menilai kredit hendaknya juga dinilai kondisi ekonomi saat ini dan kondisi ekonomi yang akandatang sesuai sektor masing-masing usaha.

\section{Pembiayaan Warung Mikro pada Bank Syariah Mandiri}

Didalam Undang-Undang (UU) Nomor 20 Tahun 2008 disebutkan bahwa Usaha mikro adalah usaha produktif milik orang perorangan dan/atau badan usaha perorangan yang memenuhi kriteria usaha mikro. ${ }^{18}$ Pembiayaan Warung mikro merupakansebuah layanan pembiayaanyang

\footnotetext{
${ }^{16}$ Adiwarman Karim, Bank Islam (Jakarta: PT. Raja Grafindo Persada, 2004), hlm. 98.

${ }^{17}$ Kasmir, Adiwarman A. Manajemen Perbakan (Jakarta: PT Raja Grafindo, 2004), hlm. 91-94.

${ }^{18}$ Undang-Undang Republik Indonesia Nomor 20 Tahun 2008 Tentang Usaha Mikro Kecil dan Menengah (Jakarta: PT. Armas Duta Raya).
} 
dimiliki oleh Bank Syariah Mandiribaik pada kantor cabang dan kantor cabang pembantu di seluruh wilayah Indonesia yang di khususkan bagi nasabah dengan kategori mikro. Landasan hukum ini didasarkan kepada Surat Edaran Pembiayaan Nomor 11/009/PEM tanggal 13 Februari 2009.

Produk Pembiayaan Warung Mikro Bank Syariah Mandiri Kantor Cabang Probolinggomerupakansalah satu dari Warung Mikro yang dimiliki oleh Bank Syariah Mandirisecara Nasional. Hadirnya Warung Mikro merupakan wujud dari misi ke-dua Bank Syariah Mandiri yakni pengembangan pembiayaan pada sektor UMKM. Pembiayaan mikro dan kecil (program) yang difokuskan kepada: pembiayaan program, pembiayaan dengan pola second tier (Linkages) dan Pembiayaan Mikro (Warung Mikro). Prinsip-prinsip pembiayaan mikro yang menjadi prinsip dan kunci sukses didalam pengelolaan pembiayaan mikro yakni proses yang cepat, sederhana dan dekat. Cepat dalam hal pencairan yang cepat agar dapat memenuhi tuntutan bisnis dengan perputaran yang tinggi. Sederhana dengan proses yang tidak berbelit-belit dan persyaratan mudah. Dekat artinya hubungan interpersonal dan lokasi layanan yang dekat dengan lokasi usaha dan segmen mikro.

Akad yang digunakan pada produk pembiayaan Warung Mikro pada Bank Syariah Mandiri ialah akad Murabahah ${ }^{19}$ Implikasi dari akad Murabahah mengharuskan adanya penjual, pembeli dan barang yang diperjualbelikan. Sebagaimana kita ketahui dalam skim pembiayaan murabahah fungsi bank adalah sebagai penjual barang untuk kepentingan nasabah dengan cara membeli barang yang dibutuhkan nasabah dan kemudian menjualnya kembali kepada nasabah dengan harga jual yang setara dengan harga beli ditambah keuntungan bank yang disebut dengan margin dan bank harus memberitahukan harga pokok barang termasuk biaya yang diperlukan dan menyampaikan semua hal yang berkaitan dengan pembelian barang kepada nasabah.

Pada aplikasinya produk pembiayaan warung mikro ini ,bank syari'ah menggunakan media "akad wakalah"dengan memberikan kuasa kepada nasabah untuk membeli barang tersebut. Dengan adanya akad wakalah maka bank sepenuhnya menyerahkan dana tersebut kepada nasabah untuk membeli barang-barang yang dibutuhkan oleh nasabah. Walaupun bank telah menggunakan akad wakalah kepada nasabah, namun bank akan tetap melakukan pengawasan terhadap barang-barang yang telah dibeli oleh nasabah agar tidak keluar dari ketentuan syari'at islam yang dijelaskan dalam fatwa DSN. Hal ini dilakukan untuk mencegah nasabah agar tidak melakukan transaksi yang dilarang, misalnya menggunakan dana pembiayaan untuk membeli barang-barang yang termasuk barang haram.

Pembahasan tentang Usaha Mikro ini meliputi pengelompokan jenis usaha berikut;yakni jenis industri skala kecil menengah dan perdagangan skala kecil dan menengah. Pada kasus di Indonesia, yang dikategorikan kedalam usaha mikro yakni usaha produktif milik perorangan dan badan usaha perorangan yang memiliki kekayaan bersih(tidak termasuk tanah dan bangunan) maksimal Rp. 50.000.000,-(Lima puluh juta rupiah) dan hasil penjualan tahunan (omzet/tahun) maskimal Rp. 300.000.000,- (Tiga ratus juta rupiah). ${ }^{20}$

\footnotetext{
${ }^{19}$ M. Yazid Afandi, M. Ag, Figh Muamalah dan Implementasinya dalam Lembaga Keuangan Syariah, (Jakarta: Gema Insani Press, 2005), hlm. 95

${ }^{20}$ Titik Sartika Pratomo dan Abd. Racman Soejono, Ekonomi Skala Kecil dan Kecil Menengah Dan Koperasi (Jakarta: Galia Indonesia, 2002), hlm. 16.
} 


\section{E. Keunggulan dan Kelemahan Usaha Mikro}

Beberapa keunggulan yang dimiliki oleh Usaha Mikro dibandingkan dengan usaha besar antara lain: ${ }^{21}(1)$ Inovasi dalam teknologi yang dengan mudah terjadi dalam pengembangan produk. (2) Hubungan kemanusiaan yang akrab di dalam usaha kecil. (3) Terdapat dinamisme manajerial dan peranan kewirausahaan.Sedangkan kelemahan yang dimiliki Usaha Mikro adalah:(1) Masalah bahan baku; Keterbatasan bahan baku dan input-input lain juga sering menjadi salah satu masalah serius bagi pertumbuhan output dan kelangsungan produksi bagi Usaha Mikro di Indonesia. Terutama selama masa krisis. (2) Keterbatasan Sumber Daya Manusia (SDM) terutama dalam aspek-aspek kewirausahaan, pengembangan produk, dan penelitian pasar.

\section{PEMBAHASAN}

\section{A. Strategi Pemasaran Pembiayaan Warung Mikro di Bank Syariah Mandiri Kantor Cabang Probolinggo.}

Bank Syariah Mandiri merupakan bank yang berbasis syariah pada bidang perbankan dengan kegiatan utamanya adalah menghimpun dan menyalurkan dana kepada masyarakat. Bank Syariah Mandiri tidak mengunakan sistem riba, hal ini dikarenakan melanggar syariah Islam.

Produk Pembiayaan Warung Mikro merupakan salah satu produk unggulan dari Bank Syariah Mandiri Kantor Cabang Probolinggo dengan menggunakan akad murabahah. Pembiayaan mikro ditujukan bagi usaha mikro (kecil) yang memiliki penghasilan di bawah ratarata namun tetap semangat melakuan usaha.

Setiap usaha yang dilakukan untuk produk pembiayaan warung mikro initidak terlepas dari strategi pemasaran. Strategi pemasaran mempunyai peran yang sangat penting dalam memasarkan produk pembiayaan di Bank Syariah Mandiri Kantor Cabang Probolinggo sebagai cara dan upaya untuk menarik calon nasabah baru maupun nasabah lama agar menjadi nasabah tetap pembiayaan mikro.

Untuk mencapai hal tersebut, strategi pemasaran produk pembiayaan warung mikro di Bank Syariah Mandiri Kantor Cabang Probolinggo dapat digambarkan dengan bagan berikut:

STRATEGI MARKETING MIX

\footnotetext{
${ }^{21}$ Titik Sartika Pratomo dan Abd. Rachman Soejono, Ekonomi Skala Kecil ..., hlm. 20
} 




Sumber: warung Mikro BSM KC Probolinggo

Dari bagan tersebut dapat dijelaskan bahwa strategi pemasaranyang digunakan oleh Bank Syariah Mandiri Kantor Cabang Probolinggo dalam upaya pencapaian target Pembiayaan Warung Mikro selaras dengan pendapat dari teori menurut Philip Kotler, yaitu strategi marketing mix yang terdiri atas product (produk), price (penetapan harga), place (tempat), dan promotion (promosi), Sedangkan starategi yang digunakan dalam melakukan promosi adalah sebagai beikut:

1. Strategi marketing door to dooryakni, merupakan kegiatan komunikasi secara langsung antara bank dengan nasabah maupun calon nasabah. Kegiatan penjualan door to door ini dilakukan dengan mendatangi langsung nasabah atau calon nasabah. Strategi ini cukup ampuh dan mudah, karena pihak bank bisa mendekatkan perusahaannya secara langsung dengan nasabah maupun calon nasabah baru dan memberikan kemudahan bagi para nasabah untuk memenuhi kebutuhannya. Dengan adanya sistem door to door ini nasabah lebih merasa nyaman karena mereka tidak perlu mendatangi bank. Karyawan marketing mikro selalu siap dan bersedia untuk datang ke rumah nasabah dengan tepat waktu yang tujuannya adalah untuk mempertahankan nasabah menjadi loyal. Selain itu, tugas seorang marketing mikro juga bertugas mencari nasabahnasabah baru yang berpotensia ${ }^{22}$. Nasabah merupakan sumber modal untuk keberlangsungan setiap kegiatan usaha. Begitu juga pada perbankan. Oleh karena itu segala keinginan, kebutuhan dan kepuasan nasabah harus betul-betul diperhatikan. Bank Syariah Mandiri harus meningkatkan jumlah nasabahnya agar dana yang terkumpul dari nasabah dapat diputar kembali dan disalurkan kepada masyarakat yang ingin melakukan pembiayaan.

2. Strategi marketingpromotion (promosi). Strategi promosi yang dilakukan Bank Syariah Mandiri Kantor Cabang Probolinggo yaitu :

${ }^{22}$ Lihat transkrip wawancara nomor, 01/1-W /F-1/13-V/2018 dalam lampiran laporan hasil penelitian ini. 
a. Melalui periklanan; ini dilakukan dalam upaya pencapaian target pembiayaan warung mikro. Media iklan dimaksud meliputi media cetak yaitu berupa brosur, majalah, koran, standing banner yang uptodate. Brosur yang ditampilkan di desain semenarik mungkin agar nasabah tertarik untuk membacanya. Selain periklanan melalui media cetak, Bank Syariah Mandiri Kantor Cabang Probolinggo juga melakukan periklanan melalui media elektronik (media internet) untuk dapat memberikan informasi kepada masyarakat.

b. Pemasaran dan penjualan langsung; ini dilakukan melalui kegiatan penjualan langsung dengan melalui grebeg pasar, sehingga nasabah (pengusaha mikro) dapat mengetahui informasi-informasi mengenai produk pembiayaan warung mikro dan kemudian berinisiatif untuk memperbesar usahanya. Di sisi lain, Bank Syariah Mandiri Kantor Cabang Probolinggo juga memanfaatkan grebeg pasar ini untuk meningkatkan image yang tertanam dibenak nasabah harus tetap dijaga, agar nasabah tetap percaya akan kualitas pelayanan yang diberikan.

3. Strategi Top UP (Penambahan Pembiayaan). Cara memasarkan atau mempromosikan produk pembiayaan warung mikro bisa dengan cara menawarkan kepada nasabah yang ingin mengajukan pembiayaan lagi atau nasabah yang Top $U p$. Cara ini sering diminati oleh nasabah yang telah melakukan pembiayaan dan membutuhkan dana tambahan.

4. Strategi Harga, Untuk dapat mensukseskan dalam proses memasarkan suatu barang atau jasa kepada konsumen, setiap perusahaan harus menetapkan harganya secara tepat. Untuk strategi harga, Warung Mikro Bank Syariah Mandiri Cabang Probolinggo menetapkan marjin yang kompetitif dibandingkan dengan margin pembiayaaan pada produk pembiayaan oleh bank lain. Harga merupakan satu-satunya taktik pemasaran yang memberikan pemasukan atau pendapatan bagi perusahaan. Jangka waktu angsuran yang ditawarkan minimal 12 bulan ( 1 tahun) sampai 48 bulan (4 tahun) sesuai plafond yang diinginkan nasabah.Mereka dapat memilih nominal angsuran yang telah tercantum didalam brosur disesuaikan dengan kemampuan nasabah dalam membayar angsuran.

Apabila dalam jangka waktu yang telah ditentukan nasabah belum dapat melunasi angsuran, mereka bisa memperoleh keringanan dengan rescedulling ataupun Restrukturing angsuran. Jika nasabah melunasi pinjaman atau menyelesaikan angsuran sebelum jatuh tempo, maka nasabah tidak akan dikenai biaya penalti namun tetap dikenai biaya administasi sebesar Rp 100.000,00. Dengan harga plafon yang murah pembiayaan warung mikro memberikan dua keuntungan sekaligus. Yang pertama, untuk meningkatnya omset karena memperoleh tambahan modal dengan persyaratan yang relatif mudahdengan biaya administrasi dan angsuran yang murah dan terjangkau.Kedua, untuk mengukur kemampuan nasabah dalam melunasi pinjaman dan mempermudah serta meringankan nasabah dalam melunasi angsuran sesuai kemampuan nasabah. Dan yang paling menarik dalam strategi harga di Bank Syariah Mandiri Kantor Cabang Probolinggo ini yaitu satu bulan menjelang bulan puasa Bank Syariah Mandiri melakukan diskon margin yang lebih murah dibanding hari-hari biasa ${ }^{23}$

5. Strategi Produk

Dalam mengembangkan produk pembiayaan Warung Mikro Bank Syariah Mandiri Kantor Cabang Probolinggo melakukan beberapa hal yaitu: (1) Menentukan Motto, ini dilakukan agar nasabah mampu memahami maksud visi dan misi yang ingin dicapai Bank Syariah Mandiri Kantor Cabang Probolinggo dalam melayani masyarakat, maka Warung Mikro juga memakai moto yang sama, yakni; "Lebih Adil dan Menentramkan" (2) Menciptakan Merk yakni Pembiayaan Usaha Mikro PUM-Madya

\footnotetext{
${ }^{23}$ Lihat transkrip wawancara nomor, 05/4-W /F-1/15-V/2018 dalam lampiran laporan hasil penelitian ini.
} 
dan PUM-Utama. Adapun faktor-faktor yang dipertimbangkan adalah Mudah diingat, Terkesan modern dan Memiliki arti yang positif.

\section{B. Faktor Pendukung dalam Pemasaran Produk Pembiayaan Warung Mikro pada Bank Syariah Mandiri Kantor Cabang Probolinggo}

Dalam menghadapi persaingan dengan bank konvensionalmaupun sesama bank syariah, Bank Syariah Mandiri Kantor Cabang Probolinggo mempunyai faktor pendukung yaitu :

1. Keunggulan Produk yang kompetitif. Dapat dilihat dari: (1) Berprinsip dan akad sesuai dengan syari'ah karena produk pembiayaan Warung Mikro merupakan produk yang menggunakan akad-akad yang sesuai dengan syari'ah Islam, antara lain: Murabahah, Wakalah, Qord dan lain-lain. (2) Limit pembiayaan mulai dari RP.11.000.000 sampai Rp200,000,000,- merupakan plafond yang dikhususkan untuk pelaku UMKM. (3) Proses pengajuan pembiayaan yang relatif mudah dan cepat yakni maksimal tiga hari sejak persyaratan lengkap.

2. Keunggulan Harga dengan menerapkan strategi berikut:(1) Angsuran ringan dan tetap hingga jatuh tempo serta disesuaikan dengan price dari record penjualan atas usaha yang dijalankan nasabah. (2) Program pelatihan dan proses pendampingan bagi usaha UMK. (3) Menggunakan pendekatan kolektif/perseorangan dan sistem jemput bola.

3. Keunggulan Tempat yakni terletak didaerah yang relatif dekat dengan lokasi usaha segmen mikro. yaitu terletak di daerah pilang, yang mana di daerah pilang rata-rata masyarakat mempunyai usaha kecil sperti toko baju, toko bahan pokok, peternak sapi dan banyak yang membutuhkan modal untuk memperbesar usahanya.

\section{Faktor Penghambat dalam Pemasaran Produk Pembiayaan Warung Mikro pada Bank Syariah Mandiri Kantor Cabang Probolinggo}

Strategi pemasaran tidak selalu berjalan dengan lancar, Setiap perusahaan tentunya menghadapi hambatan dalam usahanya. Suatu hambatan dalam perusahaan merupakan hal yang dianggap sebagai resiko dalam mencapai tujuan. yang menjadi penghambat Bank Syariah Mandiri Kantor Cabang Probolinggo dalam Memasarkan Produk pembiayaan warung mikro sebagai berikut :

1. Kurangnya Pengetahuan Masyarakat tentang system operasional perbankan syariah, terutama konsep bagi hasil atau akad-akad syariah yang digunakan, sehingga menilai bahwa Bank Syariah Mandiri sama dengan bank konvensional yang menggunakan bunga. Adapun upaya yang dilakukan untuk memberikan pengetahuan kepada masyarakat adalah menjelaskan dengan pemahaman dan bahasa yang mudah dimengerti oleh masyarakat, tentang penjelasan sistem pembiayaan yang digunakan warung mikro, yaitu dengan cara sistem bagi hasil dan akad yang digunakan menggunakan dasar-dasar Alqur'an dan Al hadits sehingga tidak mengandung riba dan tidak dilarang oleh agama.

2. Banyaknya Persaingan antar Bank yang begitu ketat dalam menarik minat masyarakat sekitar, Maka cara yang dilakukan untuk bersaing adalah dengan melakukan pengenalan secara langsung, dan memberikan wawasan dan pengenalan kepada calon nasabah, bahwa Bank Syariah Mandiri ini mempunyai karakteristik yang berbeda dengan bankbank konvensional yang berada disekitar Kota Probolinggo. 
3. Kurangnya Sumber Daya Manusia yakni khususnya karyawan bagian micro finansing sales untuk mengisi tugas-tugas yang ada di kantor cabang pembantu, walaupun sudah ada yang menempati posisi tugas tersebut. ${ }^{24}$

\section{KESIMPULAN}

Strategi pemasaran yang dilakukan oleh Bank Syariah Mandiri Kantor Cabang Probolinggo dalam upaya pencapaian target Produk Pembiayaan Warung Mikro menggunakan strategi Marketing Mix yang terdiri atas Product (produk), Promotion (Promosi), Price (Harga) dan Place (Tempat).

Sedangkan strategi promosi yang dilakukan adalah dengan (1) Strategi door to door/jemput bola yakni melakukan pemasaran dengan cara mendatangi lagsung rumah nasabah agar nasabah tertarik untuk melakukan pembiayaan warung mikro (2) Stategi promosi yaitu melalui Periklanan, pemasangan spanduk, cetak brosur untuk disebarkan di setiap Sales outlet, dan juga melakukan periklanan melalui media cetak seperti surat kabar, majalah maupun koran.(3) Strategi harga yakni dengan jangka waktu angsuran minimal 12 bulan sampai 48 bulan sesuai plafond yang diinginkan nasabah dan angsuran tetap sampai dengan jatuh tempo. (4) Strategi Top Up untuk memancing nasabah agar mereka dapat melakukan pembiayaan kembali. (5) Strategi produk, produk pembiayaan mikro di bagi menjadi 2 produk yaitu; Mikro Madya (PUM-Madya), dan Mikro Utama (PUM-Utama). keduanyamemiliki jangka waktu angsuran tersendiri.

Faktor pendukung dalam pemasaran Produk Pembiayaan Warung Mikro pada bank syariah mandiri kantor cabang probolinggo yaitu:Adanya keunggulan produk yang kompetitif, Keunggulan Harga yang ringan dan Keunggulan Tempat yang strategis.

Sedangkan faktor penghambat pemasaran produk pembiayaan warung mikro bank syariah mandiri kantor cabang probolinggo adalah: (1) Kurangnya pengetahuan masyarakat tentang sistem operasional pada perbank syariah (2) Persaingan antar bank, (3). Kurangnya sumber daya manusia terutama SDMmicro finansing sales sehingga dalam memasarkan produk kepada masyarakat luas membutuhkan waktu yang lama.

\footnotetext{
${ }^{24}$ Lihat transkrip Wawancara nomor, 04/3-W /F-2/16-V/2018 dalam lampiran laporan hasil penelitian ini.
} 


\section{DAFTAR PUSTAKA}

Antonio, Muhammad Syafi'i. Bank Syariah. Jakarta: Gema Insani, 2001.

Arikunto, Suharsimi. Prosedur Penelitian Suatu Pendekatan Praktek. Jakarta: Rineka Cipta, 1993.

Assauri, Sofjan. Manajemen Pemasaran. Jakarta: PT Raja Grafindo Persada, 2011.

Basu Swastha dan Irawan,. Manajemen Pemasaran Modern. Yogyakarta: Penerbit Leberty, 1997.

Bugis, Burhan. Metode Penelitian Kuantitatif. Jakarta: Kencana Prenada Media Group, 2005.

David Hunger dan Thomas Wheelen. Manajemen Strategis.Yogyakarta: Penerbit Andi, 2003.

Herdiansyah, Haris. Metode Penelitian Kualitatif. Jakarta: Salemba, 2010.

Ismail Nawawi Uha. Isu-Isu Ekonomi Islam 4 Nalar Bisnis. Jakarta: VIV Press Jakarta, 2013.

Kasmir. Manajemen Perbankan. Jakarta: PT Raja Grafindo Persada, 2004.

Lexy J. Moleong. Metodologi Penelitian Kualitatif Edisi Revisi. Bandung: PT Remaja Rosdakarya, 2005

Mudrajat Kuncoro. Manajemen Perbankan, Teori dan Aplikasi. Yogyakarta: BPFE, 2001.

Ridwan, Muhammad. Kontruksi Bank Syariah Indonesia. Yogyakarta: Pustaka SM, 2007.

Saefuddin, A. M. Membumikan Ekonomi Islam. Jakarta: PT. PPA Consultants, 2011.

Tjiptono, Fandy. Strategi Pemasaran. Yogyakarta: Andi Offset, 1997. 